\title{
Atomic layer deposition of amorphous tin-gallium oxide films
}

Fredrik Larsson, Jan Keller, Daniel Primetzhofer, Lars Riekehr, Marika Edoff, and Tobias Törndahl

Citation: Journal of Vacuum Science \& Technology A 37, 030906 (2019); doi: 10.1116/1.5092877

View online: https://doi.org/10.1116/1.5092877

View Table of Contents: https://avs.scitation.org/toc/jva/37/3

Published by the American Vacuum Society

\section{ARTICLES YOU MAY BE INTERESTED IN}

Status and prospects of plasma-assisted atomic layer deposition

Journal of Vacuum Science \& Technology A 37, 030902 (2019); https://doi.org/10.1116/1.5088582

A review of $\mathrm{Ga}_{2} \mathrm{O}_{3}$ materials, processing, and devices

Applied Physics Reviews 5, 011301 (2018); https://doi.org/10.1063/1.5006941

Sticking probabilities of $\mathrm{H}_{2} \mathrm{O}$ and $\mathrm{Al}\left(\mathrm{CH}_{3}\right)_{3}$ during atomic layer deposition of $\mathrm{Al}_{2} \mathrm{O}_{3}$ extracted from their impact on film conformality

Journal of Vacuum Science \& Technology A 37, 030908 (2019); https://doi.org/10.1116/1.5093620

Surface chemistry of atomic layer deposition: A case study for the trimethylaluminum/water process Journal of Applied Physics 97, 121301 (2005); https://doi.org/10.1063/1.1940727

Review Article: Atomic layer deposition of optoelectronic materials Journal of Vacuum Science \& Technology B 37, 030801 (2019); https://doi.org/10.1116/1.5083692

Tetraallyltin precursor for plasma enhanced atomic layer deposition of tin oxide: Growth study and material characterization

Journal of Vacuum Science \& Technology A 37, 030601 (2019); https://doi.org/10.1116/1.5091944

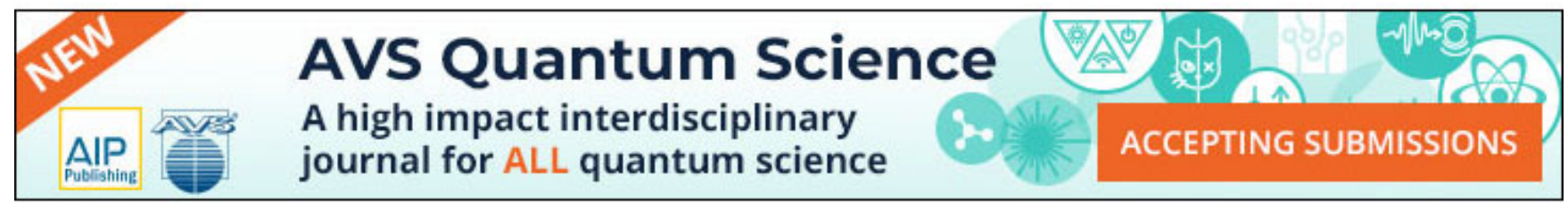




\title{
Atomic layer deposition of amorphous tin-gallium oxide films
}

\author{
Fredrik Larsson, ${ }^{1}$ Jan Keller, ${ }^{1}$ Daniel Primetzhofer, ${ }^{2}$ Lars Riekehr, ${ }^{1}$ Marika Edoff, ${ }^{1}$ and \\ Tobias Törndahl ${ }^{1, a)}$ \\ ${ }^{1}$ Department of Engineering Sciences, Solid State Electronics, Uppsala University, Box 534, SE-75121 \\ Uppsala, Sweden \\ ${ }^{2}$ Department of Physics and Astronomy, Applied Nuclear Physics, Uppsala University, Box 516, SE-75120 \\ Uppsala, Sweden
}

(Received 15 February 2019; accepted 26 March 2019; published 19 April 2019)

\begin{abstract}
A wide range of applications benefit from transparent semiconducting oxides with tunable electronic properties, for example, electron transport layers in solar cell devices, where the electron affinity is a key parameter. Presently, a few different ternary oxides are used for this purpose, but the attainable electron affinity range is typically limited. In this study, the authors develop a low-temperature atomic layer deposition (ALD) process to grow amorphous $\mathrm{Sn}_{1-\mathrm{x}} \mathrm{Ga}_{\mathrm{x}} \mathrm{O}_{\mathrm{y}}$ thin films from dimethylamino-metal complexes and water. This oxide is predicted to provide a wide selection of possible electron affinity values, from around $3 \mathrm{eV}$ for pure $\mathrm{Ga}_{2} \mathrm{O}_{3}$ to $4.5 \mathrm{eV}$ for pure $\mathrm{SnO}_{2}$. The ALD process is evaluated for deposition temperatures in the range of $105-195^{\circ} \mathrm{C}$ by in situ quartz crystal microbalance and with ex situ film characterization. The growth exhibits an ideal-like behavior at $175{ }^{\circ} \mathrm{C}$, where the film composition can be predicted by a simple rule of mixture. Depending on film composition, the growth per cycle varies in the range of $0.6-0.8 \AA$ at this temperature. Furthermore, the film composition for a given process appears insensitive to the deposition temperature. From material characterization, it is shown that the deposited films are highly resistive, fully amorphous, and homogeneous, with moderate levels of impurities (carbon, nitrogen, and hydrogen). By tailoring the metal cation ratio in films grown at $175^{\circ} \mathrm{C}$, the optical bandgap can be varied in the range from $2.7 \mathrm{eV}$ for $\mathrm{SnO}_{2}$ to above $4.2 \mathrm{eV}$ for $\mathrm{Ga}_{2} \mathrm{O}_{3}$. The bandgap also varies significantly as a function of deposition temperature. This control of properties indicates that $\mathrm{Sn}_{1-\mathrm{x}} \mathrm{Ga}_{\mathrm{x}} \mathrm{O}_{\mathrm{y}}$ is a promising candidate for an electron transport layer material in a wide electron affinity range. Published by the AVS. https://doi.org/10.1116/1.5092877
\end{abstract}

\section{INTRODUCTION}

Transparent semiconducting oxides of transition metals form a class of materials that is attractive for a wide range of applications, such as fabrication of thin-film transistors (TFTs), ${ }^{1}$ gas sensoring, ${ }^{2}$ photocatalysis, ${ }^{3}$ and as electron transport layers (ETLs) in solar cell structures. ${ }^{4}$ The conduction band minimum is often dominated by metal s-orbitals in these oxides, while the valence band maximum mainly consists of oxygen p-orbitals. ${ }^{5}$ This type of electronic structure leads to high electron mobility for many oxide materials, which can in numerous cases be preserved even if the oxide structures become disordered. That is one of the reasons why amorphous In-Ga-Zn-O (a-IGZO) has replaced a-Si as the active layer in TFTs. ${ }^{6}$ The similar electronic structures of the various transition metal oxides make alloys of two or more binary oxides highly adaptable. It is straight forward to vary properties such as electron mobility, electron affinity, and optical bandgap by simply varying the cation composition in the ternary oxide. ${ }^{7}$ This is especially true for amorphous ternary oxides, where the oxides can be freely mixed in most cases, without being restricted by possible structural differences as for crystalline materials.

The electron affinity is a key parameter for ETLs in solar cell applications and can influence the charge carrier

$\overline{{ }^{a)} E \text { lectronic mail: tobias.torndahl@angstrom.uu.se }}$ transport and recombination processes in the solar cells. ${ }^{8,9}$ It is, therefore, very attractive to apply ETLs with tunable electron affinities. Several ternary oxides have already been successfully implemented in $\mathrm{Cu}(\mathrm{In}, \mathrm{Ga}) \mathrm{Se}_{2}$ solar cells, including $\mathrm{Zn}-\mathrm{Mg}-\mathrm{O}$ and $\mathrm{Zn}-\mathrm{Sn}-\mathrm{O}$. $^{4}$ Furthermore, the choice of ETL material has also been found to be crucial for the conversion efficiency for perovskite solar cells. ${ }^{9}$ However, most of the ETLs in use today cannot be tuned to the low electron affinity values needed to form a favorable conduction band alignment to wide bandgap solar cell absorbers, by solely varying the composition.

Amorphous tin-gallium oxide (a-SGO) is a compound for which a wide range of possible electron affinity values are expected, depending on cation composition. The estimated range is from $4.5 \mathrm{eV}$ for $\mathrm{SnO}_{2}$ (Ref. 10) down to around 3 $\mathrm{eV}$ for $\mathrm{Ga}_{2} \mathrm{O}_{3} \cdot{ }^{10-12}$ It should be noted that a relatively large uncertainty in the literature data is present for the $\mathrm{SnO}_{2-}$ $\mathrm{Ga}_{2} \mathrm{O}_{3}$ system. For instance, it has been shown that the electron affinity of sputtered $\mathrm{a}-\mathrm{Ga}_{2} \mathrm{O}_{3}$ varies with deposition conditions. ${ }^{13}$ The amorphous structure is required to be able to achieve a homogeneous a-SGO due to the low solubility of the two binary oxides in each other. ${ }^{14}$ In addition, gallium substitution in crystalline $\mathrm{SnO}_{2}$ would possibly lead to charge compensation from aliovalent doping effects, which might not be desired.

To this date, tin-gallium oxide films in a wide composition range have been prepared with various deposition 
techniques, such as magnetron sputtering, ${ }^{15-17}$ sol-gel spincoating, ${ }^{18}$ and chemical vapor deposition. ${ }^{19}$

Atomic layer deposition (ALD) offers several advantages for depositing thin transparent semiconducting oxide layers. ${ }^{20}$ With ALD, it is possible to deposit uniform conformal layers in a sequential self-terminating way, where the films grow in a layer-by-layer fashion. As a result, ALD provides excellent accuracy in both thickness and composition control over large areas. Furthermore, ALD enables coating of sensitive surfaces prone to sputter-induced damage and temperature-sensitive substrates depending on the chosen precursors.

In this study, we develop a ternary ALD process to grow a-SGO by combining existing low-temperature process for $\mathrm{SnO}_{2}$ and $\mathrm{Ga}_{2} \mathrm{O}_{3}$, respectively. ${ }^{21,22}$ The process is characterized by in situ quartz crystal microbalance (QCM) to monitor growth characteristics, as well as ex situ film characterization in terms of structural properties, morphology, composition, impurity content, and optical absorption.

\section{EXPERIMENTAL DETAILS}

$\mathrm{Sn}_{1-\mathrm{x}} \mathrm{Ga}_{\mathrm{x}} \mathrm{O}_{\mathrm{y}}$ films were deposited in an F-120 laminarflow ALD system (ASM Microchemistry) at substrate temperatures in the range from 105 to $195^{\circ} \mathrm{C}$. The reactor is equipped with externally heated quartz substrate holders with space for two $25 \mathrm{~cm}^{2}$ sized substrates, where one substrate position can be replaced with a QCM sensor head. A flow of $500 \mathrm{sccm}$ highly purified $\mathrm{N}_{2}(99.9999 \%)$ ensured a pressure of around $5 \mathrm{mbar}$ in the reactor while providing an inert transport and purge gas. The $\mathrm{N}_{2}$ gas was additionally purified by using a gas filter at the reactor inlet.

The precursor used for tin was tetrakis(dimethylamino) $\operatorname{tin}(\mathrm{IV})$ [DMA $\left.4 \mathrm{Sn}, \quad\left(\left(\mathrm{CH}_{3}\right)_{2} \mathrm{~N}\right)_{4} \mathrm{Sn}\right]$ (Pegasus), where the liquid was evaporated at $40^{\circ} \mathrm{C}$ in a bubbler configuration using $\mathrm{N}_{2}$ as a carrier gas. The gallium precursor used was tris(dimethylamino)gallium(III) $\left[\mathrm{DMA}_{3} \mathrm{Ga}, \quad\left(\left(\mathrm{CH}_{3}\right)_{2} \mathrm{~N}\right)_{3} \mathrm{Ga}\right]$ (Aldrich, 98\%), which was a solid sublimed from an openboat source at $80^{\circ} \mathrm{C}$. Deionized water was used as coreactant for both metal precursors.

A supercycle approach was used to grow the ternary oxide, where A number of subcycles of $\mathrm{SnO}_{2}$ and $\mathrm{B}$ number of $\mathrm{Ga}_{2} \mathrm{O}_{3}$ subcycles were repeated in a supercycle with the pulse scheme (DMA $\left.{ }_{4} \mathrm{Sn}: \mathrm{N}_{2}: \mathrm{H}_{2} \mathrm{O}: \mathrm{N}_{2}\right)_{\mathrm{A}}:\left(\mathrm{DMA}_{3} \mathrm{Ga}_{2}: \mathrm{N}_{2}: \mathrm{H}_{2} \mathrm{O}\right.$ : $\left.\mathrm{N}_{2}\right)_{B}$, where $A: B$ or $A /(A+B)$ denotes the subcycle ratio. The pulse time was $1 \mathrm{~s}$ for all pulses, which was confirmed to be sufficiently long for saturated growth according to QCM measurements.

The substrates used were made of fused quartz which were ultrasonically cleaned in ethanol prior to ALD processing (if not otherwise specified in the text).

QCM measurements were performed to study film growth characteristics. The crystal frequency was logged by using an SQM-160 monitor (Inficon). Assuming constant temperature and pressure, the deposited mass is proportional to the negative of the measured frequency change. ${ }^{23}$ In order to quantify the deposited mass per area, we calibrated the QCM data to $\mathrm{SnO}_{2}$ and $\mathrm{Ga}_{2} \mathrm{O}_{3}$ films (grown at $175^{\circ} \mathrm{C}$ for 1000 cycles), where the films thicknesses and densities were determined using $\mathrm{x}$-ray reflectivity (XRR). Furthermore, the incoming gases were preheated at a higher temperature to ensure a constant temperature at the sensor head during pulsing of the precursors. ${ }^{24}$ All reported numerical values, extracted from the QCM curves, are averaged over at least 30 cycles.

The composition of the deposited films was characterized with x-ray fluorescence (XRF), time-of-flight elastic recoil detection analysis (ToF-ERDA), and Rutherford backscattering spectrometry (RBS). An Epsilon 5 (Panalytical) XRF spectrometer was used to determine the cation ratio in the films. RBS measurements were additionally used to calibrate the XRF relative sensitivity factor for the $\mathrm{Ga} / \mathrm{Sn}$ signal ratio. ToF-ERDA and RBS were measured using a $5 \mathrm{MV}$ tandem accelerator at the Tandem Laboratory at Uppsala University, Sweden, in order to determine the impurity level and oxygen content in the films. In ToF-ERDA, ${ }^{127} \mathrm{I}^{8+}$ ions with $36 \mathrm{MeV}$ primary energy were used as primary particles, which entered the target at an angle of $67.5^{\circ}$ with respect to the target normal. The recoiled particles were detected at a $45^{\circ}$ angle by a carbon-foil time of flight detector and by a segmented gas ionization chamber. ${ }^{25}$ RBS measurements were performed using $2.0 \mathrm{MeV}^{4} \mathrm{He}^{+}$ions incident under $60^{\circ}$ with respect to the surface normal of the target. The backscattered ions were detected at a $170^{\circ}$ scattering angle by a silicon energy detector.

The film homogeneity, morphology, structure, and density were characterized by scanning transmission electron microscopy (STEM) and XRR. A Titan Themis 200 (FEI) microscope operated at $200 \mathrm{kV}$ was used for the STEM analysis. The microscope was equipped with a high-angle annular dark-field detector (HAADF) and a super-x energy dispersive spectrometer (EDS). The sample lamellae were prepared with a focused gallium-ion beam according to the in situ lift-out method, ${ }^{26}$ in a Strata DB235 focused ion beam system (FEI). XRR was performed with a Philips X'pert MRD system (Panalytical) equipped with an X-ray mirror and parallel plate collimators, using $\mathrm{Cu} \mathrm{K}_{\alpha}$ radiation $(\lambda=1.541 \AA)$.

The optical properties of the films were characterized with reflectance and transmittance spectrophotometry (R-T), using a Lambda 900 spectrometer (PerkinElmer) equipped with an integrating sphere. The absorption coefficient was extracted by using the method described by Hong. ${ }^{27}$

\section{RESULTS AND DISCUSSION}

\section{A. ALD growth characteristics-Subcycle ratio}

The growth per cycle (GPC) as a function of the subcycle ratio is shown in Fig. 1, as recorded by QCM for depositions performed at $175{ }^{\circ} \mathrm{C}$. It can be seen that the mass gain per cycle is rather constant around $34-37 \mathrm{ng} / \mathrm{cm}^{2}$ at this temperature, with merely a slight dependency on the subcycle ratio. The resulting GPC is not constant due to differences in film density. Moreover, the GPC increases approximately linearly from $0.6 \AA$ for pure $\mathrm{SnO}_{2}$ to $0.8 \AA$ for pure $\mathrm{Ga}_{2} \mathrm{O}_{3}$. The GPC of $\mathrm{SnO}_{2}$ in our process is in 


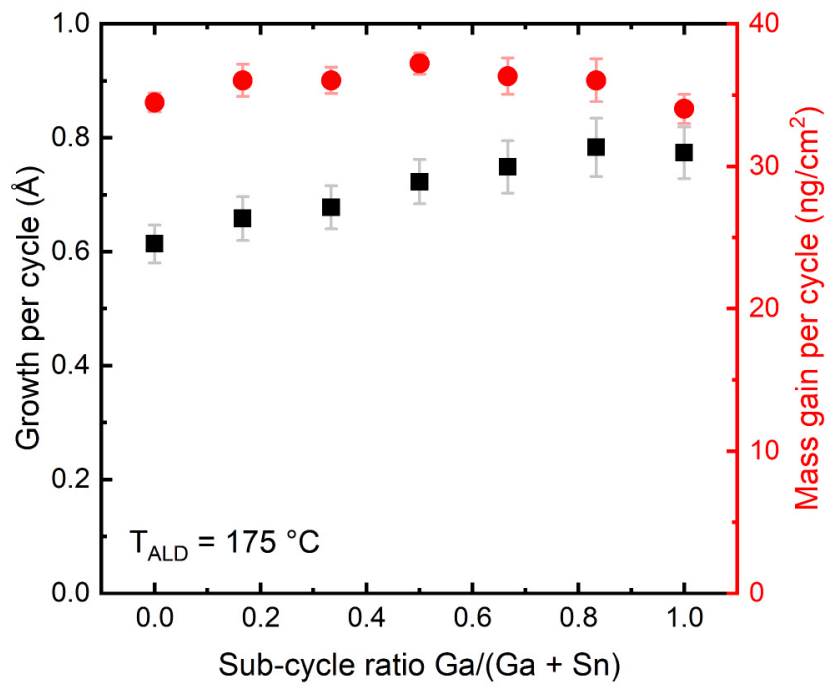

FIG. 1. GPC (squares) and mass gain per cycle (circles) vs subcycle ratio, determined by QCM for ALD $\mathrm{Sn}_{1-\mathrm{x}} \mathrm{Ga}_{\mathrm{x}} \mathrm{O}_{\mathrm{y}}$ grown at $175^{\circ} \mathrm{C}$. The error bars represent the estimated within-run standard deviation.

well agreement with literature values, ${ }^{21,28}$ whereas our $\mathrm{Ga}_{2} \mathrm{O}_{3}$ GPC is slightly lower than the reported value of $1.0 \AA .22$

QCM measurements of ALD growth of $\mathrm{SnO}_{2}, \mathrm{Ga}_{2} \mathrm{O}_{3}$, and $\mathrm{Sn}_{0.4} \mathrm{Ga}_{0.6} \mathrm{O}_{\mathrm{y}}$ (using a 1:1 subcycle ratio) are shown in Fig. 2. From the QCM curves, it is evident that the mass change during the $\mathrm{Sn}-\mathrm{O}$ and $\mathrm{Ga}-\mathrm{O}$ subcycles at $175^{\circ} \mathrm{C}$ is not significantly influenced by alternation between the two types of subcycles. The mass gain per cycle $(\Delta \mathrm{m})$ is listed in Table I, as well as the ratio between the mass gain during the metal precursor $\left(\mathrm{m}_{1}\right)$ and $\Delta \mathrm{m}$. If the growth mechanism for a given process is known, the $m_{1} / \Delta \mathrm{m}$ ratio can provide insight into the ligand-exchange reactions that typically occur during ALD growth. ${ }^{29}$ However, it has been shown that ALD of $\mathrm{SnO}_{2}$ from $\mathrm{DMA}_{4} \mathrm{Sn} / \mathrm{H}_{2} \mathrm{O}$ leads to incomplete ligandexchange reactions in the temperature region of this study. ${ }^{30}$ In our case, the exact growth mechanism for the ALD of
$\mathrm{Ga}_{2} \mathrm{O}_{3}$ is also uncertain. In addition, $\mathrm{DMA}_{3} \mathrm{Ga}$ sublimes as dimers, ${ }^{31}$ and it is unknown how this influences the chemisorption of $\mathrm{DMA}_{3} \mathrm{Ga}$ on active surface sites. Nevertheless, for the purpose of investigating if the growth mechanism is influenced by the subcycle ratio, it is sufficient to compare the $m_{1} / \Delta \mathrm{m}$ values. As listed in Table $\mathrm{I}$, the $\mathrm{m}_{1} / \Delta \mathrm{m}$ ratio for an $\mathrm{Sn}-\mathrm{O}$ subcycle is essentially the same for a mixed process with a 1:1 subcycle ratio as for a pure $\mathrm{SnO}_{2}$ process. The same holds for $\mathrm{Ga}-\mathrm{O}$. This implies either that the surfaces of growing $\mathrm{SnO}_{2}$ and $\mathrm{Ga}_{2} \mathrm{O}_{3}$ at $175^{\circ} \mathrm{C}$ are similar in terms of density of active surface sites or that the growth is limited by steric hindrance.

The near-constant mass gain per cycle at $175^{\circ} \mathrm{C}$ makes it straightforward to predict and control the film composition. In Fig. 3, the measured metal cation ratio versus subcycle ratio is plotted. RBS-calibrated XRF was used to determine the cation composition for the $62-79 \mathrm{~nm}$ thick films deposited on fused quartz substrates with 1000 ALD cycles. In addition, the data displayed in Fig. 3 include values calculated from QCM measurements.

The QCM data provide a measure of the mass gain per each individual subcycle $\left[\Delta \mathrm{m}_{\text {sub,i }}\left(\mathrm{ng} / \mathrm{cm}^{2}\right)\right.$, where $\mathrm{i}=\mathrm{Sn}-\mathrm{O}$ or Ga-O]. This makes it possible to calculate the cation composition ratio according to Eq. (1), assuming that no surface etching processes occur during the precursor pulses. In Eq. (1), $\mathrm{n}$ denotes the amount of substance, $\mathrm{M}$ denotes molar mass in $\mathrm{g} / \mathrm{mol}$, and $\mathrm{A}$ and $\mathrm{B}$ denote the number of Sn-O and Ga-O subcycles per supercycle, respectively

$$
x_{Q C M}=\frac{n_{G a}}{n_{G a}+n_{S n}}=\frac{1}{1+0.5\left(\frac{A}{B}\right)\left(\frac{M_{G a_{2} O_{3}}}{M_{S n O_{2}}}\right)\left(\frac{\Delta m_{s h b, S n-O}}{\Delta m_{s u b, b a-O}}\right)} .
$$

Furthermore, the expected composition for each subcycle ratio can be calculated based on a simple rule of mixture concept, ${ }^{32}$ in which it is assumed that the GPC is linearly dependent on the subcycle ratio. This assumption is valid when each $\mathrm{Sn}-\mathrm{O}$ or Ga-O subcycle show the same GPC as for the binary

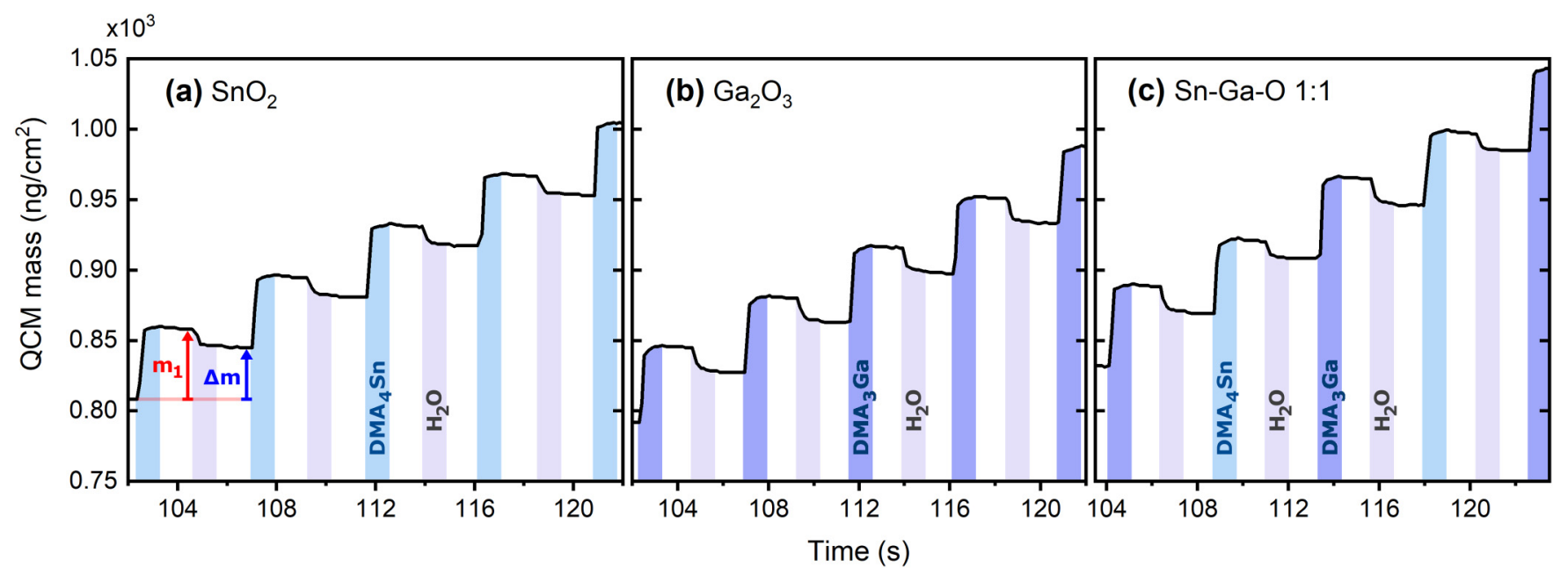

FIG. 2. QCM measurements of ALD growth of (a) $\mathrm{SnO}_{2}$, (b) $\mathrm{Ga}_{2} \mathrm{O}_{3}$, and (c) $\mathrm{Sn}_{0.4} \mathrm{Ga}_{\mathrm{o} .6} \mathrm{O}_{\mathrm{y}}$ deposited using a 1:1 subcycle ratio at a substrate temperature of $175^{\circ} \mathrm{C}$. 
TABLE I. Extracted growth parameters from QCM measurements.

\begin{tabular}{lcc}
\hline \hline Process & $\begin{array}{c}\Delta \mathrm{m} \\
\left(\mathrm{ng} / \mathrm{cm}^{2}\right)\end{array}$ & $\mathrm{m}_{1} / \Delta \mathrm{m}$ \\
\hline$T_{\mathrm{ALD}}=175^{\circ} \mathrm{C}$ & & \\
$\mathrm{SnO}_{2}$ & 36 & 1.4 \\
$\mathrm{Ga}_{2} \mathrm{O}_{3}$ & 36 & 1.5 \\
$1: 1 \mathrm{Sn}-\mathrm{O}$ subcycle & 39 & 1.3 \\
$1: 1 \mathrm{Ga}-\mathrm{O}$ subcycle & 38 & 1.5 \\
$T_{\mathrm{ALD}}=105^{\circ} \mathrm{C}$ & & \\
$\mathrm{SnO}$ & 55 & 1.2 \\
$\mathrm{Ga}_{2} \mathrm{O}_{3}$ & 37 & 1.4 \\
$1: 1 \mathrm{Sn}-\mathrm{O}$ subcycle & 45 & 1.2 \\
$1: 1 \mathrm{Ga}-\mathrm{O}$ subcycle & 43 & 1.4 \\
\hline \hline
\end{tabular}

processes for pure $\mathrm{SnO}_{2}$ and $\mathrm{Ga}_{2} \mathrm{O}_{3}$, respectively, regardless of subcycle ratio. It follows that the expected composition can be calculated by using the following:

$$
x_{\mathrm{Exp} .}=\frac{n_{\mathrm{Ga}}}{n_{\mathrm{Ga}}+n_{\mathrm{Sn}}}=\frac{1}{1+0.5\left(\frac{A}{B}\right)\left(\frac{M_{\mathrm{Ga}_{2} \mathrm{O}_{3}}}{M_{\mathrm{SnO}_{2}}}\right)\left(\frac{\Delta m\left(\mathrm{SnO}_{2}\right)}{\Delta m\left(\mathrm{Ga}_{2} \mathrm{O}_{3}\right)}\right)} .
$$

It is shown in Fig. 3 that the experimental composition values accurately follow the compositions that are expected from the simple mixing rule. This is a strong indication that the growth process at $175^{\circ} \mathrm{C}$ is mainly free from nonideal effects, such as growth inhibition by enhanced reaction activation barriers or reduced reaction site density, or surface etching effects by exchange reactions.

\section{B. ALD growth characteristics-Substrate temperature}

The growth per cycle and film composition over the temperature range of $105-195^{\circ} \mathrm{C}$ were monitored by QCM for

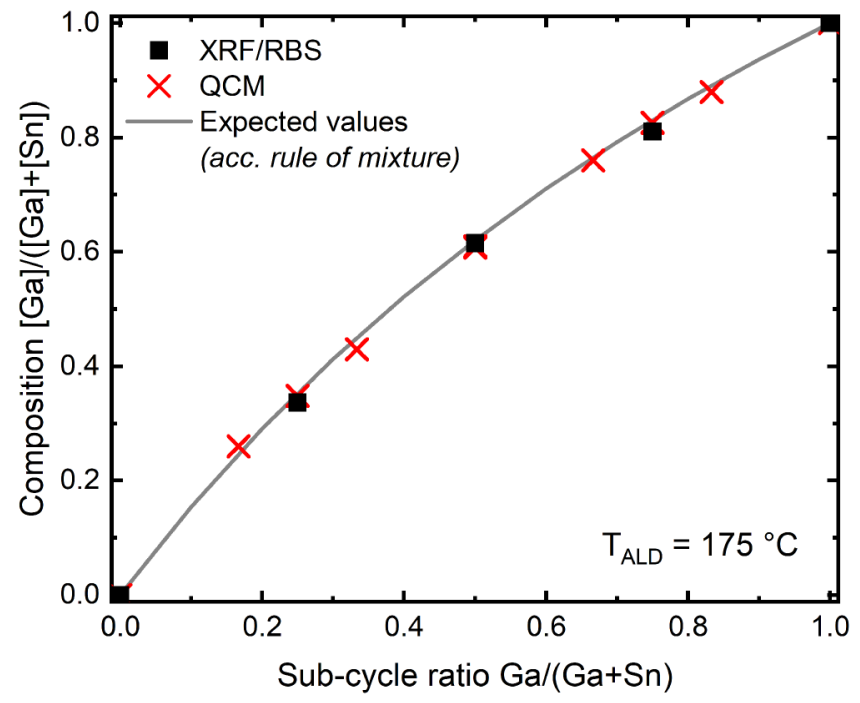

FIG. 3. Cation composition vs subcycle ratio for $A L D \mathrm{Sn}_{1-\mathrm{x}} \mathrm{Ga}_{\mathrm{x}} \mathrm{O}_{\mathrm{y}}$ films grown at $175^{\circ} \mathrm{C}$. The composition values were determined by RBS-calibrated XRF on films grown on quartz substrates $(d=62-79 \mathrm{~nm})$ or calculated from QCM data using Eq. (1). The experimental data fit very well to the expected values from Eq. (2), which assumes a simple mixing rule (solid line).
$\mathrm{SnO}_{2}, \mathrm{Ga}_{2} \mathrm{O}_{3}$, and a mixed process with a $1: 1$ subcycle ratio. This is shown in Fig. 4. It is observed that the mass gain per cycle for $\mathrm{Ga}_{2} \mathrm{O}_{3}$ is relatively unaffected by the deposition temperature in the investigated temperature range, whereas the mass gain per $\mathrm{SnO}_{2}$ cycle decreases from around $55 \mathrm{ng} / \mathrm{cm}^{2}$ at $105^{\circ} \mathrm{C}$ to $31 \mathrm{ng} / \mathrm{cm}^{2}$ at $195^{\circ} \mathrm{C}$. The substantial increase in mass gain for $\mathrm{SnO}_{2}$ at lower temperatures has previously been reported. ${ }^{28}$ A proposed explanation to this is a facilitated growth due to increased density of $-\mathrm{OH}$ groups on the surface at lower temperatures (including a possibly increased $-\mathrm{OH}$ density due to physisorption of water). ${ }^{33}$ The average mass gain per cycle for a $1: 1$ process is in-between the mass gains for pure $\mathrm{SnO}_{2}$ and $\mathrm{Ga}_{2} \mathrm{O}_{3}$, respectively (except a slight deviation for $175^{\circ} \mathrm{C}$ ). This behavior would be expected from the simple mixing rule. However, the mass gain from the individual subcycles in the 1:1 process differs from the mass gain per cycle for pure $\mathrm{SnO}_{2}$ and $\mathrm{Ga}_{2} \mathrm{O}_{3}$, at other temperatures than for $175^{\circ} \mathrm{C}$. For example, as listed in Table I, the mass gain per cycle is around 55 and $37 \mathrm{ng} / \mathrm{cm}^{2}$ for pure $\mathrm{SnO}_{2}$ and $\mathrm{Ga}_{2} \mathrm{O}_{3}$, respectively, for ALD growth at $105^{\circ} \mathrm{C}$. In the $1: 1$ process at the same temperature, the mass gain per cycle for the $\mathrm{Sn}-\mathrm{O}$ subcycle is reduced to around $45 \mathrm{ng} / \mathrm{cm}^{2}$, while the mass gain per cycle for the Ga-O subcycle is increased to $43 \mathrm{ng} / \mathrm{cm}^{2}$. If the active reaction site density is assumed to limit the GPC, then the observed trends in mass gain can be explained by a varying amount of reaction sites on the different surfaces for the different deposition temperatures, presumably $-\mathrm{OH}$ groups in this case. This is plausible since the growth is unlikely to be limited by steric hindrance, due to the variation of mass gain with temperature. If the surface density of $-\mathrm{OH}$ groups is higher on the growing $\mathrm{SnO}_{2}$ surface than on a growing $\mathrm{Ga}_{2} \mathrm{O}_{3}$ surface, at lower deposition temperatures, an intermediate $-\mathrm{OH}$ surface density is possibly obtained in the mixed 1:1 process. In that case, a reduced mass gain would, therefore, be expected for the Sn-O subcycle, and an increased mass gain for the Ga-O subcycle, as compared to the binary processes for $\mathrm{SnO}_{2}$ and $\mathrm{Ga}_{2} \mathrm{O}_{3}$.

An important feature is that the composition of an $\mathrm{Sn}_{1-\mathrm{x}} \mathrm{Ga}_{\mathrm{x}} \mathrm{O}_{\mathrm{y}}$ film grown with a 1:1 subcycle ratio is constant around $\mathrm{x}=0.6$, regardless of deposition temperature (in the range of $105-195^{\circ} \mathrm{C}$ ), as shown in Fig. 4(b). This observation suggests that the process is very robust in terms of controlling the cation composition in the films.

\section{Structural properties}

Film homogeneity and crystallinity were evaluated by STEM, using HAADF imaging and nanobeam diffraction, for an $\mathrm{Sn}_{0.4} \mathrm{Ga}_{0.6} \mathrm{O}_{\mathrm{y}}$ film deposited on soda-lime glass at 175 ${ }^{\circ} \mathrm{C}$. Figures 5(a) and 5(b) show the HAADF at low magnification and high magnification, respectively. No indications of inhomogeneities in the bulk of the $\mathrm{Sn}_{0.4} \mathrm{Ga}_{0.6} \mathrm{O}_{\mathrm{y}}$ film can be distinguished from the noise level. Therefore, if domains with varying composition exist, they are limited to a few nanometers in size. In addition, an EDS line-scan was performed over the entire the $\mathrm{Sn}_{0.4} \mathrm{Ga}_{0.6} \mathrm{O}_{\mathrm{y}}$ film [see Fig. 5(c)], which does not show any sign of a composition gradient in 

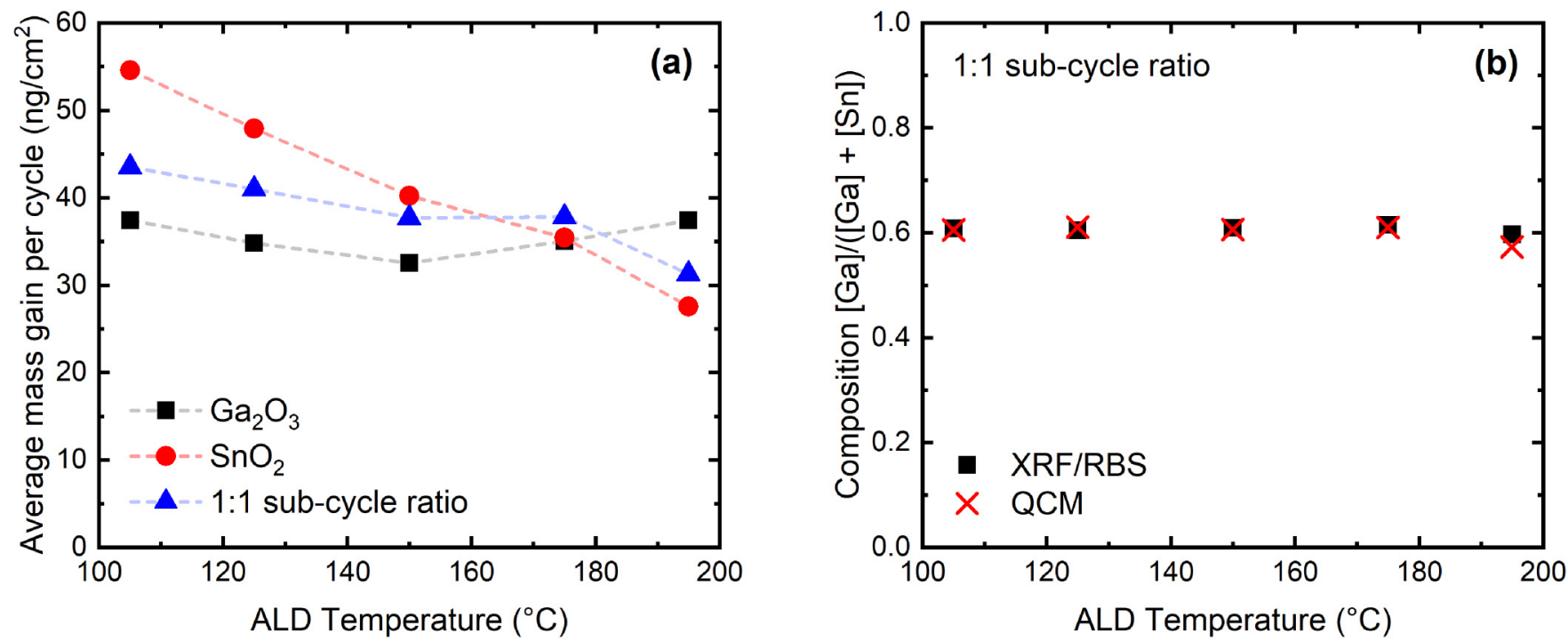

FIG. 4. (a) Average mass gain per cycle vs ALD temperature for $\mathrm{SnO}_{2}, \mathrm{Ga}_{2} \mathrm{O}_{3}$, and a mixed process with a 1:1 subcycle ratio. (b) Cation composition vs $\mathrm{ALD}$ temperature for the 1:1 mixed process, determined by RBS-calibrated XRF on films grown on quartz substrates or calculated from QCM data using Eq. (1).

the sample. In the present study, we focus on the bulk properties of the films. The interface to the substrate, which can change for different substrates due to dissimilar process initiation, remains to be studied more in detail.

Furthermore, the inset in Fig. 5(b) displays a nanobeam diffraction pattern taken from the middle of the $\mathrm{Sn}_{0.4} \mathrm{Ga}_{0.6} \mathrm{O}_{\mathrm{y}}$ film. The diffraction pattern shows diffuse rings, which confirms that the film is fully amorphous. This result is in accordance with the high magnification HAADF images in Fig. 5(b), where no nanocrystallites or ordered atomic planes

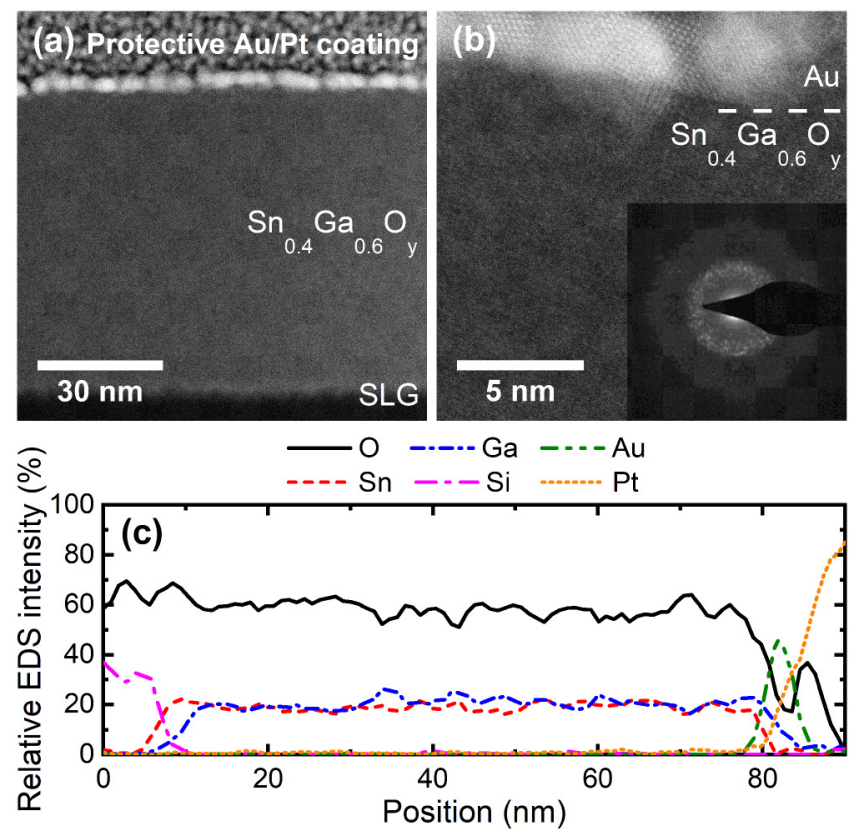

FIG. 5. (a) HAADF STEM image of a homogenous $\mathrm{Sn}_{0.4} \mathrm{Ga}_{0.6} \mathrm{O}_{\mathrm{y}}$ film deposited on soda-lime glass (SLG). (b) High-resolution STEM image and electron diffraction pattern (inset) taken from the center of the film. No atomic planes are visible in the $\mathrm{Sn}_{0.4} \mathrm{Ga}_{0.6} \mathrm{O}_{\mathrm{y}}$ layer. (c) Relative intensity from an in-depth EDS line-scan over the entire $\mathrm{Sn}_{0.4} \mathrm{Ga}_{0.6} \mathrm{O}_{\mathrm{y}}$ film. can be observed. However, the formation of nanocrystallites cannot be completely excluded, due to the limited total volume probed in STEM. Nanobeam diffraction was only performed on one sample. However, $\mathrm{x}$-ray diffraction experiments show that the deposited films are $\mathrm{x}$-ray amorphous over the entire investigated range of compositions and deposition temperatures (diffractograms not shown here).

Figure 6 shows how the $\mathrm{Sn}_{1-\mathrm{x}} \mathrm{Ga}_{\mathrm{x}} \mathrm{O}_{\mathrm{y}}$ film density varies with film composition and deposition temperature, as determined by XRR measurements on two series of samples. In the first series, $\mathrm{Sn}_{1-\mathrm{x}} \mathrm{Ga}_{\mathrm{x}} \mathrm{O}_{\mathrm{y}}$ films with the varying composition in the range $0 \leq x \leq 1$ were deposited at $175^{\circ} \mathrm{C}$. Then,

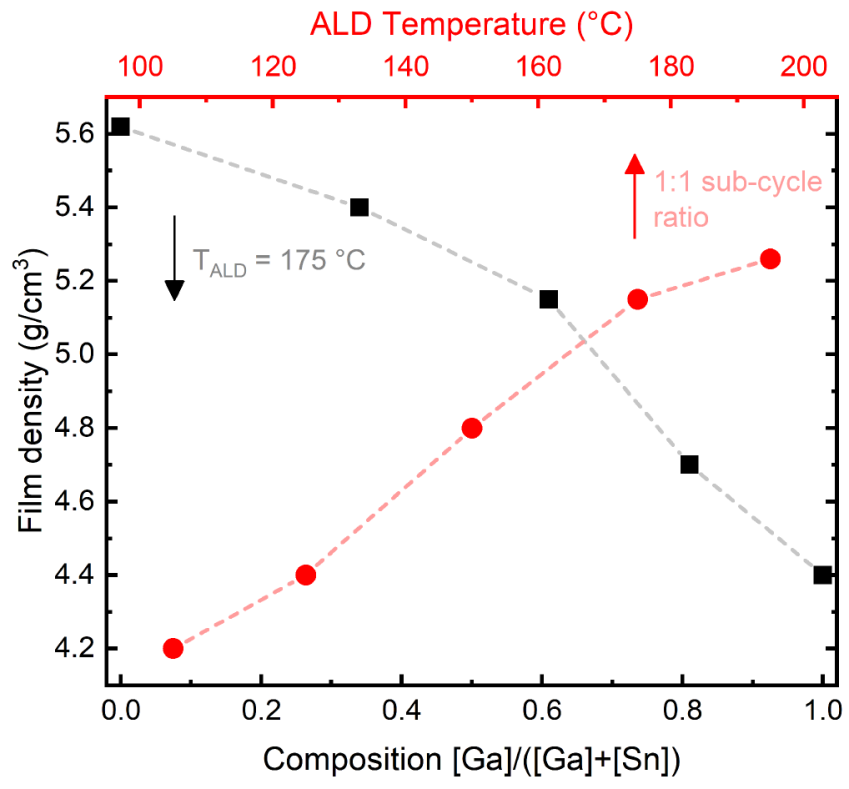

FIG. 6. Film density vs $\mathrm{Sn}_{1-\mathrm{x}} \mathrm{Ga}_{\mathrm{x}} \mathrm{O}_{\mathrm{y}}$ cation composition, determined by XRR and RBS-calibrated XRF, for samples grown at $175^{\circ} \mathrm{C}$ (squares), and film density vs ALD temperature for $\mathrm{Sn}_{0.4} \mathrm{Ga}_{0.6} \mathrm{O}_{\mathrm{y}}$ films processed using a 1:1 subcycle ratio (circles). 
films with a constant composition of $\mathrm{x}=0.6$ were deposited at varying temperatures in the range from $105^{\circ} \mathrm{C}$ to $195^{\circ} \mathrm{C}$.

The density is measured to be $5.6 \mathrm{~g} / \mathrm{cm}^{3}$ for an $\mathrm{SnO}_{2}$ film deposited at $175^{\circ} \mathrm{C}$. Here, the density is reduced with increasing $\mathrm{Ga}$ content to around $4.4 \mathrm{~g} / \mathrm{cm}^{3}$ for pure $\mathrm{Ga}_{2} \mathrm{O}_{3}$. These values are 20-25\% lower than the bulk density values of rutile $\mathrm{SnO}_{2}\left(6.99 \mathrm{~g} / \mathrm{cm}^{3}\right)$ and $\beta-\mathrm{Ga}_{2} \mathrm{O}_{3} \quad\left(5.95 \mathrm{~g} / \mathrm{cm}^{3}\right)$, respectively. ${ }^{34,35}$ This change in density may be explained by the films amorphous structure, and by residual $-\mathrm{OH}$ or other species, originating from the ligands in the metalorganic precursors, in the films.

Furthermore, the density is lower at lower deposition temperatures. The density for an $\mathrm{Sn}_{0.4} \mathrm{Ga}_{0.6} \mathrm{O}_{\mathrm{y}}$ film ranges between 4.2 and $5.3 \mathrm{~g} / \mathrm{cm}^{3}$ for deposition temperatures in the range of $105-195^{\circ} \mathrm{C}$. Lower density values for lower ALD temperatures are not uncommon for amorphous oxides and have previously been observed for $\mathrm{SnO}_{2},{ }^{36} \mathrm{Al}_{2} \mathrm{O}_{3},{ }^{37}$ and $\mathrm{SiO}_{2} \cdot{ }^{38}$ At the same time, an increased amount of residual $-\mathrm{OH}$ groups (and/or other species) are normally observed.

\section{Elemental analysis}

ToF-ERDA was used to quantify the impurity content in the films. It was found that the films contain moderate amounts of carbon, nitrogen, and hydrogen. In Table II, the concentration of the impurities are listed for $\mathrm{Sn}_{1-\mathrm{x}} \mathrm{Ga}_{\mathrm{x}} \mathrm{O}_{\mathrm{y}}$ films with varying cation composition, which were grown at $175^{\circ} \mathrm{C}$ with subcycle ratios of $3: 1,1: 1$, and 1:3. The values are corrected by RBS measurements, to compensate for an inaccurate tin quantification in the ToF-ERDA measurements, caused by overlapping signals between recoiled tin and scattered iodine. The carbon concentration in the films is around 2 at. $\%$ and the nitrogen concentration is in the range of $1-2$ at. \%, independently of the cation composition. Hydrogen is present at slightly higher levels in the range of 4-6 at. \% .

Attempts were made to use ToF-ERDA to determine the impurity content in a film grown at $105^{\circ} \mathrm{C}$ with a $1: 1$ process. Comparison of RBS and ToF-ERDA data clearly suggested that this film was prone to highly effective hydrogen release under ion bombardment in ToF-ERDA, already for very short exposure times. Note that the same film was also found to be extremely sensitive to the electron beam in STEM. By using RBS only, we can estimate the order of magnitude of impurities in the film grown at $105^{\circ} \mathrm{C}$, without suffering from any noticeable beam damage.

Figures 7(a)-7(c) show RBS spectra of $\mathrm{Sn}_{1-\mathrm{x}} \mathrm{Ga}_{\mathrm{x}} \mathrm{O}_{\mathrm{y}}$ films grown on fused quartz substrates, deposited at $175^{\circ} \mathrm{C}$ with different subcycle ratios $(3: 1,1: 1$, and 1:3). Figure $7(d)$

TABLE II. Elemental analysis by ToF-ERDA and RBS for films grown at $175^{\circ} \mathrm{C}$.

\begin{tabular}{lcccccc}
\hline \hline $\begin{array}{l}\text { Sn:Ga } \\
\text { subcycle } \\
\text { ratio }\end{array}$ & $\begin{array}{c}\mathrm{Ga} /(\mathrm{Ga}+\mathrm{Sn}) \\
(\mathrm{RBS})\end{array}$ & $\begin{array}{c}\text { Measured } \\
\mathrm{O} / \mathrm{Me} \\
(\mathrm{RBS})\end{array}$ & $\begin{array}{c}\text { Expected } \\
\mathrm{O} / \mathrm{Me}\end{array}$ & $\begin{array}{c}\text { at. \% C } \\
(\text { ERDA) }\end{array}$ & $\begin{array}{c}\text { at. \% N } \\
(\text { ERDA) }\end{array}$ & $\begin{array}{c}\text { at. \% } \mathrm{H} \\
\text { (ERDA) }\end{array}$ \\
\hline $3: 1$ & 0.33 & 1.8 & 1.9 & 1.8 & 1.4 & 3.8 \\
$1: 1$ & 0.59 & 1.7 & 1.7 & 2.2 & 1.3 & 4.8 \\
$1: 3$ & 0.77 & 1.7 & 1.6 & 1.8 & 1.5 & 5.6 \\
\hline
\end{tabular}

shows the RBS spectrum for a film grown at $105^{\circ} \mathrm{C}$ with a 1:1 subcycle ratio. From the RBS measurements, it is possible to estimate the impurity concentration by analyzing the total tin gallium and oxygen content in the films. For the films grown at $175^{\circ} \mathrm{C}$, the RBS is in accordance with ToF-ERDA. In contrast, in order to achieve a good fit between the experimental and calculated data for the film grown at $105^{\circ} \mathrm{C}$, a high impurity content must be included in the film (e.g., 35 at. $\%$ hydrogen). Due to the sensitive nature of the film, it is difficult to determine the exact ratio between hydrogen, carbon, and nitrogen impurities. However, supplementary measurements using time-resolved nuclear reaction analysis on the same film indicated the presence of high amounts of hydrogen ( $>20$ at. \%) that were quickly lost during ion irradiation (resonance energy $6.385 \mathrm{MeV}, 6.38-7.00 \mathrm{MeV}{ }^{15} \mathrm{~N}^{+}$ primary ions, data not shown here).

The oxygen-to-metal ratio was determined from the RBS spectra in Fig. 7. For the films grown at $175^{\circ} \mathrm{C}$, the oxygen-to-metal ratios match the theoretical values expected for pure $\mathrm{Sn}_{1-\mathrm{x}} \mathrm{Ga}_{\mathrm{x}} \mathrm{O}_{\mathrm{y}}$ films that maintain their charge balance (see Table II). For the film grown at $105^{\circ} \mathrm{C}$, the measured oxygen-to-metal ratio is 2.3 , as compared to the expected value 1.7. This high oxygen-to-metal ratio is likely related to the enhanced amount of hydrogen in the film, which presumably is present in the form of residual $-\mathrm{OH}$ or water.

\section{E. Optical and electrical properties}

The optical absorption in the $\mathrm{Sn}_{1-\mathrm{x}} \mathrm{Ga}_{\mathrm{x}} \mathrm{O}_{\mathrm{y}}$ films was extracted from R-T spectrophotometry measurements. The absorption coefficient spectra for different cation compositions are displayed in Fig. 8(a), for films grown at $175^{\circ} \mathrm{C}$. Figure 8(b) shows the corresponding Tauc plots, for amorphous films, which are used to extract the optical bandgap values. ${ }^{40}$ The values are plotted in Fig. 8(c).

The optical bandgap of a-SGO is evidently shifted to higher photon energies when the gallium content is increased. This observation is in line with our expectation that the bandgap and electron affinity can be tuned between the values for $\mathrm{SnO}_{2}$ and $\mathrm{Ga}_{2} \mathrm{O}_{3}$, respectively, although a shift in the conduction band minimum through decreased electron affinity remains experimentally unconfirmed. The determined optical bandgap for the $\mathrm{SnO}_{2}$ film grown at $175^{\circ} \mathrm{C}$ is $2.7 \mathrm{eV}$, which is lower than the bulk value of $3.6 \mathrm{eV}$ for rutile $\mathrm{SnO}_{2}$ phase, ${ }^{34}$ but is consistent with previously reported bandgaps for $\mathrm{SnO}_{2}$ films deposited by ALD from $\mathrm{DMA}_{4} \mathrm{Sn}$ and $\mathrm{H}_{2} \mathrm{O}{ }^{28}$ The optical bandgap of the $\mathrm{Ga}_{2} \mathrm{O}_{3}$ film grown at $175^{\circ} \mathrm{C}$ is at the limit of being determinable with the used optical setup. However, a lower limit is estimated to be $4.2 \mathrm{eV}$. Nonetheless, the bandgap is certainly lower than the value of $4.9 \mathrm{eV}$ for bulk $\beta-\mathrm{Ga}_{2} \mathrm{O}_{3}$. It is known that the optical bandgap of amorphous gallium oxide can be tuned in a relatively wide range $(\sim 4-5 \mathrm{eV})$, which has been proposed to be caused by oxygen deficiency. ${ }^{13,41}$ In our case, we do not expect the films to be oxygen deficient to a significant extent, based on the elemental analysis.

Furthermore, quite large absorption tails are observed. The origin of the tails is unknown for the a-SGO material 


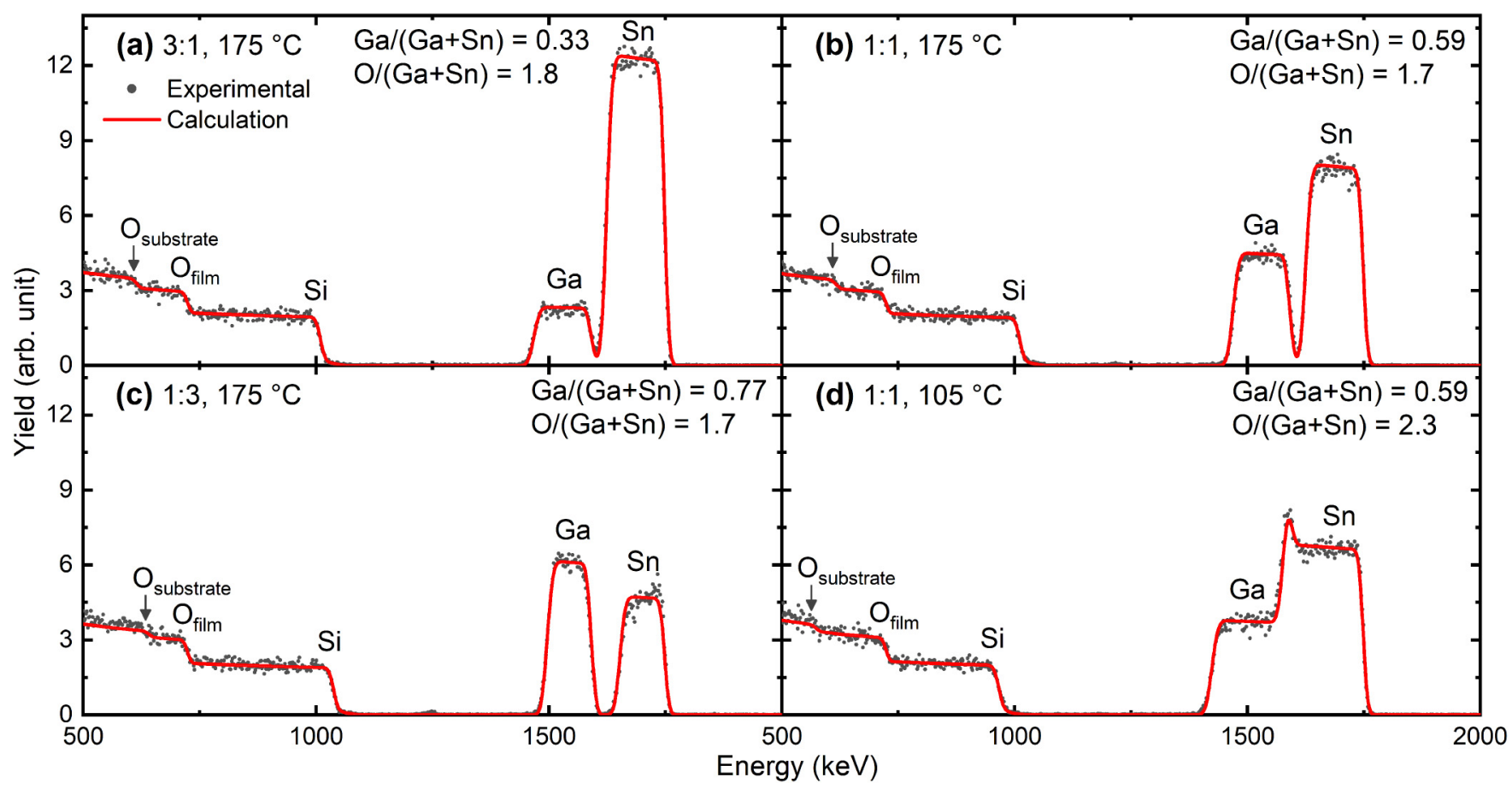

FIG. 7. (a)-(c) RBS spectra of $\mathrm{Sn}_{1-\mathrm{x}} \mathrm{Ga}_{\mathrm{x}} \mathrm{O}_{\mathrm{y}}$ films, deposited on fused quartz at $175^{\circ} \mathrm{C}$ with 1000 cycles with subcycle ratios of $3: 1,1: 1$, and $1: 3$, respectively. (d) RBS spectrum of a film grown at $105{ }^{\circ} \mathrm{C}$ with a $1: 1$ subcycle ratio. All spectra were recorded using $2.0 \mathrm{MeV}^{4} \mathrm{He}^{+}$primary ions with an incidence angle of $60^{\circ}$. The simulated spectra were calculated using the sIMNRA software (Ref. 39).
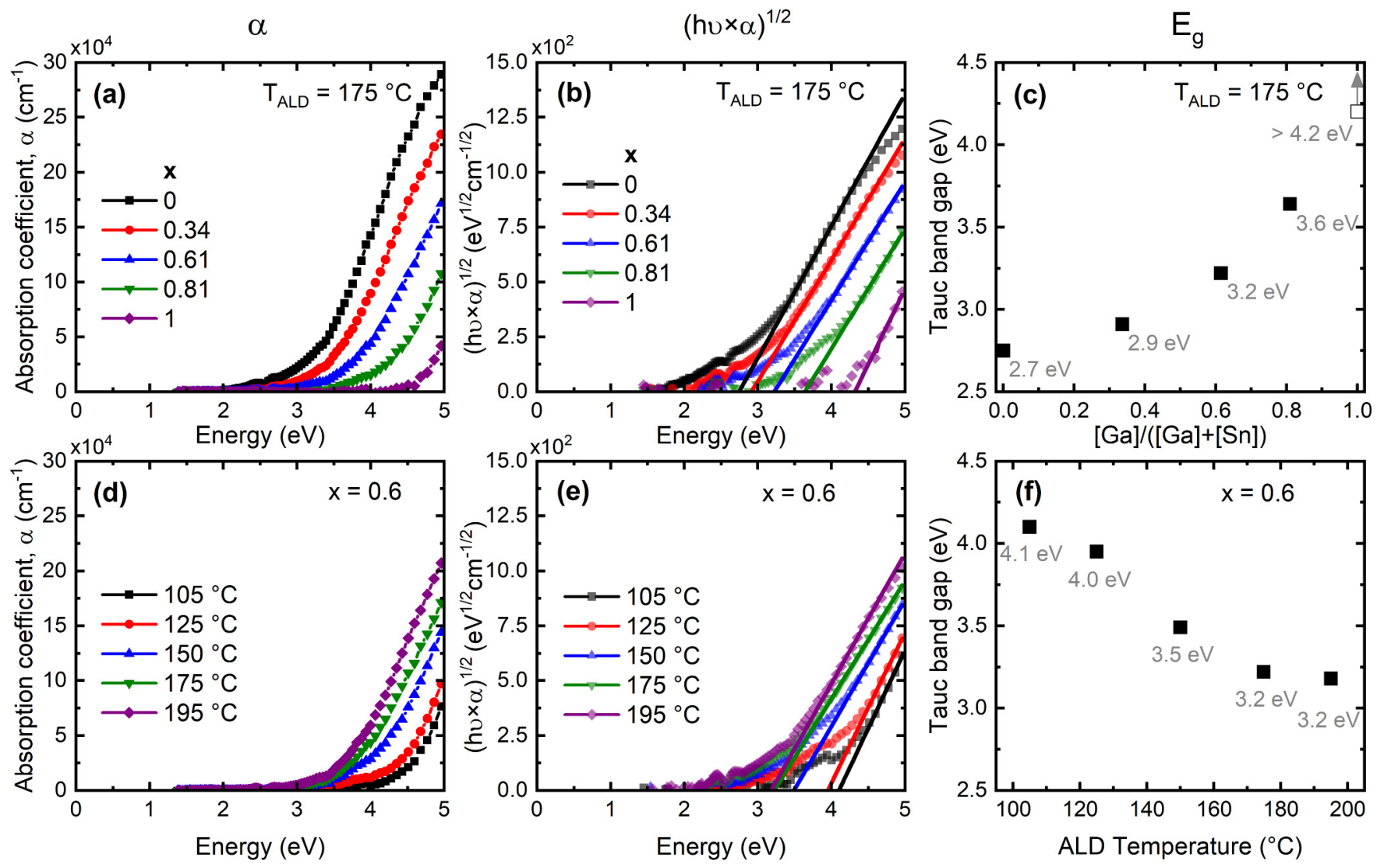

FIG. 8. Optical absorption coefficient of $\mathrm{Sn}_{1-\mathrm{x}} \mathrm{Ga}_{\mathrm{x}} \mathrm{O}_{\mathrm{y}}$ films vs composition for films grown at $175^{\circ} \mathrm{C}$ (a) and vs $\mathrm{ALD}$ temperature for films with $\mathrm{x}=0.6$ (d), with corresponding Tauc plots (b) and (e). The extracted optical band gaps are plotted vs composition (c) and ALD temperature (f). 
system. However, it is plausible that the tails are due to localized oxygen p-states above the valence band, which is known to produce absorption tailing in other similar amorphous semiconducting oxides. ${ }^{42-44}$

Interestingly, the deposition temperature also has a significant effect on the optical bandgap of $\mathrm{Sn}_{1-\mathrm{x}} \mathrm{Ga}_{\mathrm{x}} \mathrm{O}_{\mathrm{y}}$ films with a constant composition of $x=0.6$. The effect of deposition temperature on the optical properties of these films is seen in Figs. 8(d)-8(f), which show the absorption coefficients, Tauc plots, and extracted optical bandgaps, respectively. The measured optical bandgap is $4.1 \mathrm{eV}$ for a $\mathrm{Sn}_{0.4} \mathrm{Ga}_{0.6} \mathrm{O}_{\mathrm{y}}$ film grown at $105^{\circ} \mathrm{C}$ as compared to $3.2 \mathrm{eV}$ when grown at $195^{\circ} \mathrm{C}$. The temperature-induced bandgap shift can have different causes. Firstly, the films are homogenous and amorphous layers, which are not likely to exhibit any microstructural features that can produce a bandgap shift (see Sec. III C). Instead, the shift is possibly caused by the enhanced impurity content or due to an overall structural change in the amorphous network, which in turn alters the electronic structure. For instance due to altered average interatomic distances, as evidenced by the observed distinct change in film density (the average Me-Me distance in the films increases by $20-25 \%$ when the growth temperature is decreased from 195 to $105^{\circ} \mathrm{C}$ according to data from XRF and XRR). In the present study, it is not possible to distinguish between the two possible effects. A more detailed study is required to pinpoint the exact mechanism.

It is clear that the optical (and electronic) properties of a-SGO can be tuned continuously in a controlled way, both by manipulating the cation composition and by varying the deposition temperature. This fulfills a key criterion for using a-SGO as a tunable electron transport layer, in, for instance, solar cell applications.

Two other relevant properties for electron transport layers are the carrier concentration and resistivity. In this study, all deposited a-SGO films are extremely resistive, which is in accordance with the measured stoichiometric metal to oxygen ratios. The resistivity values are larger than $10^{4} \Omega \mathrm{cm}$, as measured using a van der Pauw setup, ${ }^{45}$ whereas the resistivity of an $\mathrm{SnO}_{2}$ film grown at $175^{\circ} \mathrm{C}$ was measured to be in the $10^{4} \Omega \mathrm{cm}$ range. Due to the high resistivity of a-SGO, it was not practically possible to determine the carrier mobility in this setup. However, assuming mobility values in the range of $1-100 \mathrm{~cm}^{2} /(\mathrm{Vs})$, a resistivity value higher than $10^{4} \Omega \mathrm{cm}$ corresponds to a carrier concentration value lower than $10^{13}-10^{15} \mathrm{~cm}^{-3}$.

\section{F. Note on precursor purity}

High precursor quality is essential for a well-functioning ALD process. We have noticed that it can occur that commercial $\mathrm{DMA}_{3} \mathrm{Ga}$ precursors contain relatively high amounts of chlorine, which presumably originate from the synthesis process. An established route to synthesize $\mathrm{DMA}_{3} \mathrm{Ga}$ is through a one-pot salt synthesis route using $\mathrm{GaCl}_{3}$ and $\mathrm{LiN}\left(\mathrm{CH}_{3}\right)_{2}{ }^{46}$

The chlorine contamination has two direct consequences. Firstly, the deposited $\mathrm{Ga}_{2} \mathrm{O}_{3}$ (or a-SGO) films also contain the chlorine contaminant. For instance, we have measured around 7 at. $\% \mathrm{Cl}$ concentration in $\mathrm{Ga}_{2} \mathrm{O}_{3}$ films using different $\mathrm{DMA}_{3} \mathrm{Ga}$ suppliers, which roughly corresponds to a $\mathrm{Ga} / \mathrm{Cl}$ ratio of 5 . If it is assumed that the $\mathrm{Ga} / \mathrm{Cl}$ ratio in the precursor is maintained during deposition, which is likely due to the inability of the adsorbed $-\mathrm{Cl}$ species to react with water at the low deposition temperatures in this study, a $\mathrm{Ga} / \mathrm{Cl}$ ratio of 5 corresponds to approximately 0.8 at. $\% \mathrm{Cl}$ in the precursor. If incautious, this may falsely appear to be a low concentration of contamination.

Secondly, the ALD growth is severely affected as well. The growth mechanism (and GPC) is modified, where the QCM curves indicate the presence of two chemisorption processes (not shown here).

It should be noted that for the films in this present paper, no chlorine could be detected by x-ray photoelectron spectroscopy, RBS, or ToF-ERDA.

\section{CONCLUSIONS}

A low-temperature process was successfully developed for the fabrication of high resistivity a-SGO thin films by ALD from dimethylamino-metal complexes and water.

QCM studies revealed that the growth exhibits an ideallike behavior at $175^{\circ} \mathrm{C}$, where the composition can be predicted by a simple rule of mixture. Depending on film composition, GPC varies in the range of $0.6-0.8 \AA$, at this temperature. At lower temperatures, the growth per individual subcycle ( $\mathrm{Sn}-\mathrm{O}$ or $\mathrm{Ga}-\mathrm{O}$ ) differs from the corresponding GPC values in pure $\mathrm{SnO}_{2}$ or $\mathrm{Ga}_{2} \mathrm{O}_{3}$ processes and therefore deviates from the rule of mixture. Despite this, the composition of $\mathrm{Sn}_{\mathrm{x}-1} \mathrm{Ga}_{\mathrm{x}} \mathrm{O}_{\mathrm{y}}$ films fabricated using a 1:1 subcycle ratio was constant at $\mathrm{x}=0.6$ over the entire studied ALD temperature range $\left(\mathrm{T}=105-195^{\circ} \mathrm{C}\right)$. This contributes to an overall good process stability.

Detailed characterization of deposited films showed that the films are fully amorphous and homogenous. It was also discovered that the film density changes not only with composition but also with ALD temperature to a large degree (a $20 \%$ density reduction was observed when the growth temperature decreased from 195 to $105^{\circ} \mathrm{C}$ for an $\mathrm{Sn}_{0.4} \mathrm{Ga}_{0.6} \mathrm{O}_{\mathrm{y}}$ film). This distinct density change indicates an extensive modification of the amorphous network. In addition, the density reduction is associated with elevated impurity levels for lower deposition temperatures, notably by a higher hydrogen content.

Optical characterization confirmed that the optical bandgap shifts continuously from $2.7 \mathrm{eV}$ for $\mathrm{SnO}_{2}$ to above $4.2 \mathrm{eV}$ for $\mathrm{Ga}_{2} \mathrm{O}_{3}$ (for films grown at $175^{\circ} \mathrm{C}$ ). This is in line with the expectation that one should be able to shift the optical bandgap and electron affinity from the values for pure $\mathrm{SnO}_{2}$ to those of $\mathrm{Ga}_{2} \mathrm{O}_{3}$, by mixing of the two amorphous materials. However, it was also found that the optical bandgap is strongly influenced by the ALD temperature as well, where the optical bandgap increases from 3.2 to $4.1 \mathrm{eV}$, when the ALD temperature is decreased from 195 to $105^{\circ} \mathrm{C}$ for an $\mathrm{Sn}_{0.4} \mathrm{Ga}_{0.6} \mathrm{O}_{\mathrm{y}}$ film.

Since the optical and electronic properties can be accurately controlled in a continuous manner, ALD grown a-SGO films are believed to have a large potential for many applications, such as the implementation as a tunable 
electron transport layer in solar cell devices and other applications.

\section{ACKNOWLEDGMENTS}

The authors gratefully acknowledge financial support from the Swedish Energy Agency (Grant No. 2017-004796) and support by VR-RFI (Contract No. 2017-00646 9) and the Swedish Foundation for Strategic Research (SSF, Contract No. RIF14-0053) for accelerator operation. They are also grateful to Katharina Rudisch and Mallikarjuna Rao Motapothula for assisting with ToF-ERDA measurements.

${ }^{1}$ K. Nomura, Science 300, 1269 (2003).

${ }^{2}$ A. Dey, Mater. Sci. Eng. B 229, 206 (2018).

${ }^{3}$ M. R. Hoffmann, S. T. Martin, W. Choi, and D. W. Bahnemann, Chem. Rev. 95, 69 (1995).

${ }^{4}$ W. Witte, S. Spiering, and D. Hariskos, Vak. Forsch. Prax. 26, 23 (2014).

${ }^{5}$ T. Kamiya and H. Hosono, NPG Asia Mater. 2, 15 (2010).

${ }^{6}$ X. Yu, T. J. Marks, and A. Facchetti, Nat. Mater. 15, 383 (2016).

${ }^{7}$ J. E. Medvedeva, D. B. Buchholz, and R. P. H. Chang, Adv. Electron. Mater. 3, 1700082 (2017).

${ }^{8}$ A. Niemegeers, M. Burgelman, and A. De Vos, Appl. Phys. Lett 67, 843 (1995).

${ }^{9}$ K. Mahmood, S. Sarwar, and M. T. Mehran, RSC Adv. 7, 17044 (2017).

${ }^{10}$ M. N. Islam and M. O. J. Hakim, Mater. Sci. Lett. 5, 63 (1986).

${ }^{11}$ W. Guo, Y. Guo, H. Dong, and X. Zhou, Phys. Chem. Chem. Phys. 7, 5817 (2015).

${ }^{12}$ H. Park, J. H. Choi, K. M. Choi, D. K. Lee, and J. K. J. Kang, Mater. Chem. 22, 5304 (2012).

${ }^{13}$ M. D. Heinemann, J. Berry, G. Teeter, T. Unold, and D. Ginley, Appl. Phys. Lett. 108, 022107 (2016).

${ }^{14}$ G. Palmer and K. Poeppelmeier, Solid State Sci. 4, 317 (2002).

${ }^{15}$ T. Matsuda, K. Umeda, Y. Kato, D. Nishimoto, M. Furuta, and M. Kimura, Sci. Rep. 7, 44326 (2017).

${ }^{16} \mathrm{~T}$. Yang et al., Thin Solid Films 518, 5542 (2010).

${ }^{17}$ Y. Huang, Z. Ji, and C. Chen, Appl. Surf. Sci. 253, 4819 (2007).

${ }^{18}$ C. Y. Tsay and S. C. Liang, J. Alloys Compd. 622, 644 (2015).
${ }^{19}$ X. Du, Z. Li, C. Luan, W. Wang, M. Wang, X. Feng, H. Xiao, and J. J. Ma, Mater. Sci. 50, 3252 (2015).

${ }^{20}$ S. M. George, Chem. Rev. 110, 111 (2010).

${ }^{21}$ J. W. Elam, D. A. Baker, A. J. Hryn, A. B. F. Martinson, M. J. Pellin, and J. T. J. Hupp, J. Vac. Sci. Technol. A 26, 244 (2008).

${ }^{22}$ Dezelah, J. Niinistö, J. Arstila, L. Niinistö, and C. H. Winter, Chem. Mater. 18, 471 (2006).

${ }^{23}$ G. Z. Sauerbrey, Für Phys. 155, 206 (1959).

${ }^{24}$ M. N. Rocklein and S. M. George, Anal. Chem. 75, 4975 (2003).

${ }^{25}$ P. Ström, P. Petersson, M. Rubel, and G. Possnert, Rev. Sci. Instrum. 87, 103303 (2016).

${ }^{26}$ R. M. Langford and M. Rogers, Micron 39, 1325 (2008).

${ }^{27}$ W. Q. J. Hong, J. Phys. D. Appl. Phys. 22, 1384 (1989).

${ }^{28}$ M. N. Mullings, C. Hägglund, and S. F. Bent, J. Vac. Sci. Technol. A 31, 061503 (2013).

${ }^{29}$ J. W. Elam and S. M. George, Chem. Mater. 15, 1020 (2003).

${ }^{30}$ A. J. M. Mackus, C. MacIsaac, W.-H. Kim, and S. F. Bent, J. Chem. Phys. 146, 052802 (2017).

${ }^{31}$ O. T. Beachley, G. E. Coates, and G. J. Kohnstam, J. Chem. Soc. (Resumed) 0, 3248 (1965).

${ }^{32}$ S. T. Christensen and J. W. Elam, Chem. Mater. 22, 2517 (2010).

${ }^{33}$ J. T. Tanskanen and S. F. Bent, J. Phys. Chem. C 117, 19056 (2013).

${ }^{34}$ M. Batzill and U. Diebold, Prog. Surf. Sci. 79, 47 (2005).

${ }^{35}$ S. I. Stepanov, V. I. Nikolaev, V. E. Bougrov, and A. E. Romanov, Rev. Adv. Mater. Sci. 44, 63 (2016).

${ }^{36}$ J. Lindahl, C. Hägglund, J. T. Wätjen, M. Edoff, and T. Törndahl, Thin Solid Films 586, 82 (2015).

${ }^{37}$ M. D. Groner, F. H. Fabreguette, J. W. Elam, and S. M. George, Chem. Mater. 16, 639 (2004).

${ }^{38}$ Y. S. Lee, D. Choi, B. Shong, S. Oh, and J. S. Park, Ceram. Int. 43, 2095 (2017).

${ }^{39}$ M. Mayer, AIP Conf. Proc. 475, 541 (1999).

${ }^{40}$ J. Tauc, Mater. Res. Bull. 3, 37 (1968).

${ }^{41}$ J. Kim et al., NPG Asia Mater. 9, e359 (2017).

${ }^{42}$ Y. Kang, H. Song, H. H. Nahm, S. H. Jeon, Y. Cho, and S. Han, APL Mater. 2, 032108 (2014).

${ }^{43}$ W. Körner, D. F. Urban, and C. Elsässer, Phys. Status Solidi A 212, 1476 (2015).

${ }^{44}$ W. Körner and C. Elsässer, Thin Solid Films 555, 81 (2014).

${ }^{45}$ L. J. van der Pauw, Philips Res. Rep. 13, 1 (1958).

${ }^{46}$ K. M. Waggoner, M. M. Olmstead, and P. P. Power, Polyhedron 9, 257 (1990). 